\title{
På vinnersporet igjen
}

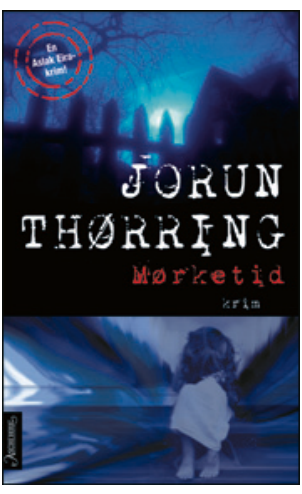

Scenen er satt i gynekologen Jorun Thørrings femte kriminalroman når et skjelett bokstavelig faller ut - ikke av skapet - men en rusten gammel varmtvannstank. Stedet for hendelsen er et nedlagt og for lengst fraflyttet elevinternat et stykke utenfor Tromsø sentrum.

Boken er også forfatterens åpne oppgjør med dette og andre tilsvarende institusjoner som i tiårene etter den annen verdenskrig ble drevet i offentlig eller privat regi. Med bred pensel maler Thørring bildet av en privat anstalt drevet av en kristelig organisasjon der krav om lydighet og underkastelse, og vanskjøtsel og overgrep, hørte til dagens orden. Om elevene allerede var traumatisert og stigmatisert, ble de ikke mindre skadeskutt etter årene med streng kristen kjærlighet bak en velfrisert fasade.

Drapsetterforsker Aslak Eira faller naturlig inn i bildet. Med sin samiske bakgrunn og en alkoholavhengig far har han selv en fortid fra et liknende internat under oppveksten i Finnmark. Underveis i arbeidet med å oppklare et åpenbart mord og forsøkene på holde sporene av det skjult, blir han til alt overmål stilt ansikt til ansikt med en nemesis fra barndommen. Det vekker bare onde minner hos vår helt.

Forfatteren kommer selv fra området og tegner internatet og omgivelsene med sikker hånd på en måte som gjør det lett å kjenne en isnende vind med bølgeklukk fra fjæresteinene og høre resignerte hulk og sukk fra de internerte, den tidens «les miserables». Det er heller ikke vanskelig å føle uhyggen som sitter i veggene underveis i oppklaringen av det opprinnelige drapet og de som følger i tur og orden. Følelsen vedvarer helt frem til den overraskende vendingen historien tar mot slutten. Akkurat der er Thørring helt på topp igjen med samme nerve som i hennes to første bøker $(1,2)$.

Fortellingen har tre persongallerier. Kollegene på «kammeret» og rettspatologen er de samme og like forutsigbare som før. Selv Eiras assistent Kine Berger er nå plassert mer kledelig i bakgrunnen. Uttrykket profesjonell avstand mellom henne og sjefen er bare forbokstaven denne gangen. Til gjengjeld er alle ansatte på Fredheim og de voksne, tidligere elevene beskrevet tydelig, men litt stereotypisk. Det er nesten ingen formildende trekk å se hos noen av de foresatte, og barna har det stort sett gått dårlig med senere i livet. Selv de få som tilsynelatende har klart seg bra, har en tynn ferniss det er lett å få hull på. Heldigvis tipper det aldri over, og alle karakterene fremstår som troverdige på sin måte. Og «han Aslak sjøl» har da visst kommet gjennom internatoppholdet sitt på helhjertet vis, eller ...?

Boken med den talende tittelen Mørketid er fint avstemt når den pendler mellom nåtid og året 1973 med de dramatiske hendelsene som lå bak og fant sted i løpet av noen lite varmende sommermåneder. Thørring behersker historien fra den aktuelle tiden og bekrefter samtidig at hun har nødvendig faglig innsikt til å beskrive langtidseffekten og sekvelene hos noen av barna det gjaldt. Hun har fortsatt anatomi- og patologikunnskapene inne, inkludert de som skyldes vold og overgrep.

I Glassdukkene opptrådte drapsmannen flere ganger underveis som hovedpersonen i fortellingen, der han formidlet sine vurderinger, planer og neste trekk (2). Denne gangen opptrer morderen på samme måte, men nå som jeg-person. Det gjelder både i fortid som daværende internatelev og i nåtid. Det siste er svært effektfullt og gir en annerledes innlevelse i lesingen. Oppklaringen utvikler seg overraskende. Til gjengjeld blir selve slutten litt melodramatisk.

Jorun Thørring fikk mye oppmerksomhet på sensommeren i år da denne boken kom samtidig som lanseringen av den første filmen om Aslak Eira og hans Tromsø-univers. Ikke uventet dukket kollega Mads Gilbert opp i filmrollen som den radikale anestesilegen alle dro kjensel på i Glassdukkene (2). Mens Mørketid fikk gode mottakelser, gjaldt det ikke det samme for filmen. Til Thørrings unnskyldning hører det med at hun ikke hadde noen befatning med filmmanuskriptet som bygget på begge de to første bøkene om politimannen fra nord $(2,3)$.

Siden hennes første bok kom ut i 2005, har Jorun Thørring plassert seg svært synlig i rekken av fremgangsrike norske krimforfattere. Dersom handlingen i den neste boken legges til Paris, er det da for mye forlangt at hennes andre helt - Orla Os, opprinnelig fra Vesterålen - også får seg kjæreste?

\section{Geir W. Jacobsen}

Tidsskriftet

\section{Litteratur}

1. Thørring J. Skyggemannen. Oslo: Aschehoug, 2005

2. Thørring J. Glassdukkene. Oslo: Aschehoug, 2006

3. Thørring J. Ildens øye. Oslo: Aschehoug, 2009 